\title{
The future of reference service
}

\section{A panel discussion held at the University of Texas at Austin, Spring 1988.}

\begin{abstract}
A held at the University of Texas at Austin General Libraries during the Spring of 1988. The promotional material for the program posed the following questions: Will there be any reference librarians in the future? Can a person's information needs be met by a computer program? Is the reference desk essential to providing reference services? Should there be multiple reference desks and should reference users be screened through various levels of reference staff before they are referred to or given an appointment with the appropriate reference specialist?

The program was sponsored by the Library's Reference and Information Services Committec.
\end{abstract}

The attendees included academic and special librarians from the central Texas area, library school faculty and students, paraprofessionals, and general faculty.

The keynote address was given by Barbara Ford, the associate director of the Trinity University Library. Her talk was followed by responses from Goldia Hester, reference librarian, and Larayne Dallas, engineering reference librarian, both from the University of Texas at Austin. Their presentations were then followed by a lively discussion both among members of the audience and between the audience members and the panel. Their addresses and a summary of the audience comment by Dennis Dillon are presented here.

\section{Reference service: Past, present, and future}

\author{
By Barbara J. Ford \\ Associate Library Director \\ Trinity University
}

\section{History and background}

In 1876 Samuel Green, a public librarian, stated in American Library Journal that "personal intercourse and relations between librarians and readers are useful in all libraries." "This was the first explicit proposal for a program of personal assistance

${ }^{1}$ Samuel S. Green, "Personal Relations between Librarians and Readers," American Library Journal 1 (November 30, 1876):79. to readers. Initially, personal assistance was regarded as primarily useful to create a better impression on the library's users. ${ }^{2}$ Objections to per-

\footnotetext{
${ }^{2}$ The volume by Samuel Rothstein, The Development of Reference Services through Academic Traditions, Public Library Practice and Special Librarianship (Chicago: ALA/Association of College \& Research Libraries, 1955), ACRL Monographs, no. 14, was the basis for much of the information in this paper on the origin and development of reference services.
} 